\title{
Violence against adolescents: an analysis based on the categories gender and generation*
}

\author{
VIOLÊNCIA CONTRA ADOLESCENTES: UMA ANÁLISE À LUZ DAS CATEGORIAS \\ GÊNERO E GERAÇÃO
}

\author{
LA VIOLENCIA CONTRA ADOLESCENTES: UN ANÁLISIS A LA LUZ DE LAS CATEGORÍAS \\ GÉNERO Y GENERACIÓN
}

\section{Rafaela Gessner ${ }^{1}$, Rosa Maria Godoy Serpa da Fonseca ${ }^{2}$, Rebeca Nunes Guedes de Oliveira ${ }^{3}$}

\begin{abstract}
Exploratory and descriptive study based on quantitative and qualitative methods that analyze the phenomenon of violence against adolescents based on gender and generational categories. The data source was reports of violence from the Curitiba Protection Network from 2010 to 2012 and semi-structured interviews with 16 sheltered adolescents. Quantitative data were analyzed using SPSS software version 20.0 and the qualitative data were subjected to content analysis. The adolescents were victims of violence in the household and outside of the family environment, as victims or viewers of violence. The violence was experienced at home, mostly toward girls, with marked overtones of gender violence. More than indicating the magnitude of the issue, this study can give information to help qualify the assistance given to victimized people and address how to face this issue.
\end{abstract}

\section{DESCRIPTORS}

Violence

Adolescent

Violence against women

Domestic violence

Adolescent health

\section{RESUMO}

Objetivo: Analisar a violência contra o adolescente à luz das categorias gênero e geração. Método: Estudo exploratório, descritivo, de abordagem quantitativa e qualitativa. As fontes de dados foram as notificações de violência da Rede de Proteção do município de Curitiba, de 2010 a 2012, e entrevistas semiestruturadas com 16 adolescentes abrigados. As variáveis quantitativas foram analisadas pelo software SPSS e os dados qualitativos através da análise de conteúdo. Resultados: Os adolescentes foram submetidos à violência no ambiente doméstico e fora dele, como vítimas ou como espectadores. Prevaleceu no domicílio, incidindo principalmente sobre as meninas, com marcada conotação de violência de gênero. Conclusão: Mais que constatar a magnitude do problema, o estudo pode fornecer subsídios para qualificar a assistência prestada aos sujeitos vitimizados e subsidiar o enfrentamento do fenômeno.

\section{DESCRITORES \\ Violência \\ Adolescente \\ Violência contra a mulher \\ Violência doméstica \\ Saúde do adolescente}

\section{RESUMEN}

Objetivo: Analizar la violencia contra los adolescentes a la luz de las categorías de género y generación. Método: Estudio exploratorio, descriptivo, de abordaje cuantitativo y cualitativo que. Las fuentes de datos fueron las denuncias de violencia mantenidos por la Red de Protección en Curitiba entre los años 2010-2012 y entrevistas semi-estructuradas con 16 adolescentes alojados. Las variables cuantitativas se analizaron mediante el programa SPSS y los cualitativos por la análisis de contenido. Resultados: Los adolescentes fueron sometidos a la violencia en el hogar y en el exterior, como víctimas o espectadores. La violencia fue más frecuente en el hogar, centrándose principalmente en las chicas con matices marcados de violencia de género. Conclusión: Más que encontrar la magnitud del problema, el estudio puede servir de base para calificar la asistencia a las personas víctimas de este fenómeno.

\author{
DESCRIPTORES \\ Violencia \\ Adolescente \\ Violencia contra la mujer \\ Violencia doméstica \\ Salud del adolescente
}

\footnotetext{
* Extract from the dissertation "Violência contra o adolescente: uma análise à luz das categorias gênero e geração", School of Nursing, University of São Paulo, 2013. ${ }^{1}$ Master of Sciences, Nursing Graduate program, School of Nursing, University of São Paulo, São Paulo - São Paulo, Brazil. ${ }^{2}$ Full Professor, Department of Collective Health Nursing, School of Nursing, University of São Paulo, São Paulo - São Paulo, Brazil. ${ }^{3}$ Post Doctoral, Department of Collective Health Nursing, School of Nursing, University of São Paulo, São Paulo - São Paulo, Brazil. 


\section{INTRODUCTION}

Violence against adolescents is a current phenomenon that represents a significant problem for the health field, especially because of the high mortality rate with which it is associated. It is more frequent in emergent countries, such as Brazil, where social disparity and insufficient public policies ${ }^{(1)}$ attract attention. Data from the World Health Organization (WHO) show that, annually, more than a million deaths are caused by interpersonal or collective violence or self-harm, especially in the 15- to 44-year-old demographic. WHO recognizes such violence as one a major world problem in the health field because of its potential to result in injuries, death, psychological damage and development deficiency ${ }^{(2)}$.

Studies point to the high incidence and impact of violence, especially domestic violence, against children and adolescents in different parts of the world. Research carried out in the U.S., Chile, Egypt, India and the Philippines has shown that physical aggression for educational purposes is not limited to just a few places in the world, being found in all of the researched countries. More severe punishment, such as striking with objects, were registered with higher incidence in India (35\%), Egypt (26\%) and the Philippines (21\%), while in Chile and in the U.S. this index is $4 \%$. Moderate physical aggression, such as striking with the hands, presented an incidence of $75 \%$ in the Philippines, 58\% in India, 51\% in Chile, $47 \%$ in the U.S. and $29 \%$ in Egypt $^{(2)}$.

Specifically in Brazil, data from the National Council for the Rights of Children and Adolescents (Conselho Nacional dos Direitos da Criança e do Adolescente) show that 6.5 million children and adolescents suffer some type of domestic violence annually; every day 18,000 are beaten and 300,000 are victims of incest ${ }^{(3)}$. In Brazil, in 2011, there were 24,654 reports of some kind of violence against adolescents. Physical violence was identified as the most frequent against adolescents in the age group from 10 to 14 years, corresponding to $36 \%$ of the notifications; in second place was sexual violence, at $28.3 \%$. In the age group from 15 to 19 years, physical violence was responsible for $59.6 \%$ of the notifications, followed by psychological violence $(16 \%)$ and sexual violence $(10.9 \%)^{(4)}$.

Frequently, violence against adolescents has fatal consequences: a study revealed that Brazil has the fourth highest number of homicides against children and adolescents (13 homicides/100,000 children and adolescents) among 92 countries. This number is 150 times higher than found in countries such as England, Portugal, Spain and Egypt ${ }^{(4)}$.

Certainly, violence against children and adolescents causes a greater social impact when it results in problems such as homicide and incest; however, when it is manifested through socially acceptable methods, such as spanking, it is trivialized. In this context, it can be said that currently there is no real problematization of violence as the effect of the relations of power established in society, resulting in the phenomenon being treated in an isolated manner ${ }^{(5)}$. It is imperative to deepen the discussion about this issue, starting from an understanding of violence as a historically and socially constructed phenomenon. From that perspective, violence against adolescents is a phenomenon that is inherent in the contradictions present in generational, gender, class and ethnic-racial relations of domination and exploitation that are generally asymmetrical.

The naturalization of the majorities' power over minorities is a fact that subjugates adolescents to the authority supposedly represented by gender, age, skin color and wealth. Understood through a social perspective, such attributes translate into the categories gender, generation, race/ethnicity and social class. We stress that, when it involves adolescents and adults, violence is also based on inequities of generational power, which may lead to or amplify social disparities ${ }^{(6)}$.

It is understood that recognizing the size of the problem of violence against adolescents is fundamental to breaking the cycle of violence inside and outside the family that affect society, making it possible to act directly on its prevention and confrontation. Thus, it is necessary to go beyond case reporting, with the development of measures for the promotion of equity in gender and generational relations that value adolescents as citizens.

Concerning the confrontation with violence against children and adolescents in Brazil, the city of Curitiba has been developing effective actions for confronting and preventing violence, being a pioneer in the development of the Protection Network for Children and Adolescents at Risk for Violence (Rede de Proteção à Criança e ao Adolescente em Situação de Risco para a Violência). The Protection Network, created in the year 2000 , consists of a set of actions that are integrated and intersectoral to prevent violence and protect children and adolescents who are at risk. It acts through the creation of preventive measures with the objective of confronting the problem and contributing to a cultural change related to this question, with the objective of early intervention in situations of violence ${ }^{(7)}$. The severity of the cases reported through the Network, the limited number of this type of studies about reports related to adolescents, and the magnitude with which the phenomenon of violence acts in the life of adolescents justified the execution of this study, which defines as the object of investigation the phenomenon of violence against adolescents reported in the city of Curitiba and its articulation with gender and generational issues.

This study had as its general objective the analysis of the phenomenon of violence against adolescents 
from the perspective of the categories gender and generation. The specific objectives were to understand the characteristics of violence against adolescents from the reports of the Curitiba Network of Protection, and to analyze the profile and know the reality of violence against adolescents sheltered in the city. The objective of the study is to promote actions guided by the principles of collective health, taking into consideration the categories gender and generation, to expand recognition of the scope of the problem and allow a glimpse of possibilities for confronting violence against adolescents as part of the work of the Network.

\section{METHOD}

This was an exploratory and descriptive study with a quantitative and qualitative approach. The sites were the Protection Network for Children and Adolescents at Risk of Violence and four shelters in the city.

The secondary source was the Protection Network database, corresponding to the years 2010 to 2012, composed of information from reports of suspected or confirmed cases of violence against adolescents registered by the health, education or social assistance services. Data were analyzed with SPSS software, version 20.0. All the presented results were calculated based on the total of valid cases, in other words, the forms that were filled out in the database. Analysis was based on descriptive statistics and on the performance of tests for comparison among the variables. The association between two variables was analyzed using the chisquare test. When the calculated significance value $(p)$ was lower than 0.05 , the difference between associations was considered statistically significant.

Data from primary sources were collected through semi-structured interviews with adolescents who lived in shelters linked to nongovernmental organizations in Curitiba. Interviews were performed in the institutions between April and May 2013. Interviews were recorded, transcribed and submitted to content analy$\operatorname{sis}^{(8)}$. The speeches were identified with the letter A, followed by the letters $F$ or $M$ to indicate the interviewee's gender, and numbered according to the order in which they were performed.
Data analysis was guided by the categories gender and generation. The gender category corresponds to the understanding of the relations, built historically and socially, between genders. Gender differentiates biological sex from social sex and is, according to a fundamental tenet of social relations, based on the perceived differences between the genders; it constitutes the first manner of signifying the relations of power ${ }^{(9)}$.

However, it is understood that the gender category cannot be used individually to interpret violence. It is necessary to search for the understanding of reality through an amalgam of social categories (gender, race and generation), focusing on one or another, or the sum of many, depending on the phenomenon to be analyzed ${ }^{(6)}$. Therefore, to understand violence against adolescents, it was necessary to incorporate the generation category in the analysis. The concept of generation makes it possible to differentiate what separates and what connects, for example, children and adolescents from the adults, as well as, as an analytical category, to appropriate the dynamic variations that are historically produced and elaborated in the relations between children and adults ${ }^{(10)}$.

The project was submitted for approval to the Research Ethics Committee of the College of Nursing of the University of São Paulo, under protocol number 222.566.

\section{RESULTS}

In the years 2010, 2011 and 2012, 6,677 cases of violence were reported against adolescents from 10 to 18 years of age. There were 2,093 cases in 2010, 2,322 in 2011 and 2,262 in 2012. Female adolescents were marginally more affected by violence $(50.52 \%)$ than male adolescents (48.48\%). Regarding age groups, $63.96 \%$ were victims of 10 to 14 years of age, with a higher incidence in the year 2010 of $66.79 \%$.

Violence prevailed in subjects of Caucasian ethnicity (72.83\%), followed by mixed (22.78\%) and black (4.21\%). It was noted that the city's population is mostly white $(78.88 \%)^{(11)}$, explaining the higher occurrence of cases in this population sphere. The most common type of violence was negligence, followed by physical and sexual violence (Table 1).

Table 1 - Reports of violence against adolescents, according to type of violence - Curitiba, 2010 to 2012

\begin{tabular}{|c|c|c|c|c|c|c|c|c|}
\hline \multirow{2}{*}{ Type of violence } & \multicolumn{2}{|c|}{2010} & \multicolumn{2}{|c|}{2011} & \multicolumn{2}{|c|}{2012} & \multicolumn{2}{|c|}{ Total } \\
\hline & $\mathbf{n}$ & $\%$ & $\mathbf{n}$ & $\%$ & $\mathbf{n}$ & $\%$ & $\mathbf{n}$ & $\%$ \\
\hline Negligence & 1.211 & 57.86 & 1.351 & 58.18 & 1.331 & 58.83 & 3.893 & 58.30 \\
\hline Physical & 435 & 20.78 & 446 & 19.21 & 403 & 17.90 & 1.284 & 19.23 \\
\hline Sexual & 282 & 13.48 & 335 & 14.43 & 351 & 15.50 & 968 & 14.50 \\
\hline Psychological & 147 & 7.02 & 187 & 8.05 & 175 & 7.72 & 509 & 7.63 \\
\hline Abandonment & 18 & 0.86 & 3 & 0.13 & 2 & 0.09 & 23 & 0.34 \\
\hline Total & 2.093 & 100.00 & 2.322 & 100.00 & 2.262 & 100.00 & 6.677 & $100.0 \mathrm{C}$ \\
\hline
\end{tabular}

Source: CE/SMS - Database from the Protection Network, Curitiba, 2013.

Violence against adolescents: an analysis based on the categories gender and generation Gessner R, Fonseca RMGS, Oliveira RNG 
The instances of violence against adolescents happened more frequently in the household $(77.19 \%)$, being of all types: negligence (75.48\%), physical (11.93\%), sexual $(6.79 \%)$, psychological (5.35\%) and abandonment $(0.45 \%)$. The cases of violence outside of the family (20.21\%) involved physical violence $(49.70 \%)$, sexual violence $(44.80 \%)$, psychological violence $(4.68 \%)$ and negligence $(0.82 \%)$. In addition, $2.60 \%$ of the reported cases were about self-harm.

The type of violence presented a significant statistical difference $(p=0.001)$ in relation to the victim's gender. Negligence was more frequent in male victims $(67.58 \%)$ than female victims $(49.21 \%)$. Physical violence was more prevalent in the males $(22.70 \%)$ and sexual violence was more frequent among females (25.44\%).

For both female and male victims, the mothers were the main aggressors (34.54\%), followed by both parents $(20.60 \%)$ and by strangers (11.15\%). However, the perpetrator of the violence changed depending on the type of violence, since the aggressor's gender presented a significant association $(p<0.001)$ to the type of violence. Concerning negligence, the mother was the main aggressor (52.93\%), followed by both parents (33.64\%). Regarding physical violence, there was aggression perpetrated by strangers $(35.51 \%)$, by the father $(13.86 \%)$ and by acquaintances (11.37\%). Concerning sexual violence, $88.22 \%$ of the reported cases were perpetrated by male aggressors. The main predators were acquaintances of the victims (27.69\%), strangers $(27.58 \%)$ and stepfathers $(12.70 \%)$. Of special note was the percentage of sexual violence perpetrated by family members (33.16\%).

In the current study, the qualitative data were used to describe reality, bringing to life the situations showed by the quantitative data. The qualitative data highlight questions about and details of the adolescents' lives, to facilitate reader comprehension of what was quantitatively revealed. Sixteen sheltered adolescents participated in the qualitative stage: 11 girls and five boys. The age varied from 12 years to 17 years; six were of Caucasian ethnicity, six were mixed and four were black. Education level varied from the fourth year of Brazilian primary school to the second year of Brazilian high school. Through analysis of the adolescent's accounts, two empirical categories were obtained: Life marked by violence; and the adolescent facing violence: No one believes me

\section{Life marked by violence}

The accounts of the adolescents revealed the violence present in their daily lives. The practice of physical aggression was reported as a habitual means of resolving family conflicts, which may be demonstrated by the following excerpt:
Every time that he [father] wanted something and I said I wouldn't do it for him, he would beat me up (AF6).

The data refer to the gravity of the violent situation. The position of subalternity of gender and generation that defines the adolescent victims prevents them from assuming a position of defense.

I was sleeping, he [father] came, threw me to the floor, started kicking me, pressing my throat with his foot, started beating me up (AF6).

It was possible to note that the cycle of violence, especially sexual, when it happens mainly in the family space, is difficult to break. Many times, the situation is hidden by families for fear of breaking the family unit. In this context, the victim resorts, for example, to divine intervention while waiting for the solution to the problem.

My stepfather and my uncle, too [committed sexual abuse]. I always used to tell my mother, but she used to tell me to leave it in God's hands. What did she want? (AF5).

Violence is present in family relations and in community spaces, making the adolescents sometimes victims, sometimes spectators of the phenomenon.

My father used to come home drunk, my mother used to come home tired and he used to beat my mother up (AM12).

The neighborhood was very slummy, there was too much gunfire, too much death and such (AF4).

\section{The adolescent facing violence: No one believes me}

We found that it is difficult for adolescents to recognize violence as such, although they gave accounts of physical aggression. Naturalization makes the episodes so banal that they come to be perceived as something common and expected.

Never, [violence did not happen] not with me, but my father used to beat me up (AF3).

The adolescents' accounts showed impotence when facing the aggressors, a condition imposed by the subordinate position that they occupy in the relations of gender and generation. The domination that the aggressors exert over the victims may be expressed in different ways, by economical imbalance, physical force and, especially, by psychological mechanisms of oppression, which intensify fear and justify the threats.

$\mathrm{He}$ (father) pointed the gun at me; he had a gun at home. I had nothing else to do, or I would die or... [Made gestures referencing the sexual act] (AF9).

Another cause for concern regarding sexual violence against female adolescents is that they are frequently accused of provoking the problem, being blamed for the violence. The following account shows this, emphasizing the socially accepted and legitimized discourse that some 
women, because of their behavior, clothing, speech or the way they walk, ask to be sexually abused.

For my family I am useless (...) I behave in a happy way, you know? I laugh a lot, and then people think that I am a hussy. Therefore, for my family that was it, I was throwing myself at my father. Then, because of that, it [the rape] happened, that is what they used to say (AF09).

\section{DISCUSSION}

The analysis of reality made it possible to understand violence against adolescents as a phenomenon that starts in the disparate power relations with the objective of domination. Predominant in the space of relations inside the family, these relations find in the categories gender and generation establishing elements that justify and naturalize, ideologically, power and domination and have in common the fact that they are natural attributes with social meanings, organized by privileges ${ }^{(12)}$.

The percentage of domestic violence found in this study was higher than that described in the Surveillance System for Violence and Accidents (Viva) 2006-2007 report, which identified that $50 \%$ of the reports of violence against adolescents happened in the household ${ }^{(13)}$. These findings make it clear that most reports were caused by persons who should take care of and protect adolescents; but, on the contrary, they perpetrate violence in its most diverse forms.

The reports for negligence were significant. According to the protocol of the Protection Network, negligence happens when the needs and basic care for physical, emotional and social development of adolescents are not provided $^{(7)}$. Although it is a form of violence which is difficult to identify, because it involves social, cultural and economic aspects ${ }^{(14)}$, it was the most frequent during the three years covered by the study.

Physical violence, the second most frequent form among the reports analyzed, refers to a historical and social construction that is intimately placed in the family culture of our society. The cultural value of domestic education preserves the concept that children are properties of parents and that, in order for them to be educated, it is necessary that they be punished by those who occupy a higher position in the gender and generational hierarchy when they are insubordinate ${ }^{(15)}$.

Violence may also be perpetrated by other agents, in different environments. It is a mechanism used in conflicts between groups of young people, such as, for example, in nightclubs, neighborhoods and schools; therefore, it can fuel a pattern of living with and responding to physical violence $^{(16)}$. The reflection of this pattern of living may be related to the high number of incidents of physical violence that were revealed in the space outside the family of the area where the study was conducted.
The fact that the mothers were the main reported aggressors may be related to a significant increase in the number of women who have taken on chief and complete responsibility for the family. In Curitiba, $41.46 \%$ of households are under the responsibility of women, a higher percentage than found in the state of Parana (35.64\%) and in Brazil as a whole $(38.74 \%)^{(11)}$. Although this index represents, on the one hand, a change in the socioeconomic profile of Brazilian women and their greater presence in the labor market, on the other hand, it represents a large percentage of women in charge of fully providing for the family and who concentrate on the maintenance of the house and of the family and the responsibility for raising their children, frequently without the minimum necessary support, be it from the family or from the state. As a result, it is noted that unequal relations of social class increase inequalities related to gender and generation. The uncertainty of the social situation in which women live, in addition to their subordinate condition in life, that bar them from providing dignified living conditions for themselves and their children $\neg$, may explain the high occurrence of negligence cases ${ }^{(14)}$. In addition to these aspects, there are the social meanings that caring for children is a female attribute, in a way that, when it is neglected, it is associated to the mother figure ${ }^{(12)}$.

As for sexual violence, the fact that most of the aggressors were acquaintances of the victims may be explained by the increase in relations built in the public space in adolescence, determined by gender and generation constructs that determine vulnerability for the adolescent population. However, we cannot discard the hypothesis that abuse perpetrated by acquaintances outside the family may be more easily reported by adolescent victims, since, in these cases, the chronicity and silence pact, common when the abuse takes place in the household, may not be present.

The results of this research confirm the findings of a study ${ }^{(16)}$ that claimed that violence affects boys and girls differently. Therefore, when analyzing the phenomenon with the chosen analytical categories, it is understood that sexual violence is associated with gender violence, where the meanings that compose the social image of females are ingrained, determining subalternity and domination in the lives of the adolescents, whose identification as girls may put them in a subordinate social rank that, in addition to generational subalternity, makes the phenomenon even more important ${ }^{(12)}$. This aspect determines specific necessities, socially produced, that are related to the process of formation of society and the health-disease process of the population ${ }^{(17)}$.

The qualitative analysis of the adolescents' accounts revealed a discourse of social acceptance of physical violence as an educational tool. The fact that the aggression starts directly on the face and the neck carries with it the highest expression of who holds the power in the relation, in other words, the one who can mark the victim,
Violence against adolescents: an analysis based on the categories gender and generation Gessner R, Fonseca RMGS, Oliveira RNG 
stamping the physical mark of force and affecting physical beauty, an attribute that is socially valued by adolescents.

The accounts of adolescent sexual victims show that, among the different types of violence, sexual violence is the least reported by families, especially because of fear of breaking the family unit ${ }^{(18)}$. The silence pact between aggressor and victim has potential to cover what happened, to help the denial of evidence and signs of abuse, in the name of loyalty and family union. Children and adolescents are victimized both by the aggressors and by the existence of networks of silence and complicity, not only by member of the family, but also by neighbors, friends, and education and health professionals who, when silent about the situations of violence of which they are aware or which they suspect, end up protecting the aggressors and making it difficult to confront the problem ${ }^{(19)}$.

The situations faced by the interviewees paint a picture of violent daily life in large Brazilian cities, which exhibit intense social and economic disparity, pushed by capitalist means of production ${ }^{(20)}$. For adolescents living in this context of extreme disparity, rising unemployment, social, cultural and moral exclusion, and the resulting lack of options, violence becomes a real alternative in their lives, starting with the inclusion of children and adolescents into organized crime $^{(21)}$.

Frequently, for adolescents, violence is understood as something much greater or more serious and different from what happens commonly in their daily lives. From that comes the difficulty of perceiving themselves as victims and recognizing the violent relations in which they are inserted ${ }^{(20)}$. This naturalization may be explained by the meanings assumed in the intergenerational relations of power, seeing as the power of the oldest over the youngest, or of the father over the son, is used as an argument that legitimizes and justifies violence as an allowed and appropriate resource by adults in family life. The mark of the generation category intensifies the difficulty for adolescents of breaking free from violent situation, as it legitimizes the status quo of domination of the youngest by the oldest.

The account of the victim sexually abused by her father at gunpoint represents the strongest form of coercion against the victim by the aggressor: the threat against life to satisfy their desires and give them pleasure. In this context, physical violence, threats and fear are aspects that contribute to the upkeep of the silenced sexual abuse ${ }^{(22)}$.

It is noted that blaming adolescents for sexual abuse establishes a dangerous inversion of roles that perpetuates the naturalization of this kind of gender violence, where the predators assume the position of victims and of being a hostage to their sexual instincts, instead of being blamed. The impact of gender inequalities on these adolescents shapes the control and force of aggressors, where victims have no autonomy or freedom of choice. Gender disparity is one of the great contradictions of society, and it has continued throughout history and relegated women to a subordinate social position. One of the extreme manifestations of this phenomenon is violence against women (in this study, violence against female adolescents), which derives from asymmetry of power that translates to relations of power and domination ${ }^{(23)}$.

In synthesis, it may be ascertained that violence against adolescents reduces the victims to the status of objects. The adults, in this relation, express their power over the more vulnerable individuals through violence. For adolescent victims, the devaluation and low self-esteem generated by these episodes may be responsible for their perpetuation in future affective relations and for difficulties in their development as subjects of their own history ${ }^{(24)}$.

\section{CONCLUSION}

Violence perpetrated against adolescents is supported by asymmetries of power between generations and genders. Although it generally happens equally to both genders, the analysis of the reports concluded that violence manifests differently for boys and girls. This shows that gender determination, in some cases, surpasses generation determination, for example in cases of sexual violence that happened mainly to girls and in cases of physical violence that happened mostly to boys.

Reality shows adolescent victims of violence as nonprotagonists of their own citizenship, since they do not have guarantees of their social rights, in both the household and the environment outside of their families. In these environments adolescents are exposed to the most diverse social inequalities, unemployment, little or no possibility of social ascension and community violence greatly intensified by neocapitalist means of production that define the society in which we live, being as the social construction of relations naturalizes adults' power over adolescents and, thus, justifies dominance over the weak.

Impotence in facing aggressors disqualifies adolescents from intergenerational and intergender relations. Fear of aggressors, built on threats, silences victims when it comes to the suffered aggression. This relation of power, which is extremely unequal among victim-aggressorfamily, constitutes a triad where violence is veiled, naturalized and silenced, not only by victims, but also by other persons in the family sphere.

The Protection Network is a strategy that points to the possibility of confronting and overcoming the problem of violence against adolescents, since it develops actions that contribute to a shift in the paradigm that considers violence a natural phenomenon. However, despite advances in data reporting, it is still crucial to invest in this sphere, because it is known that many of incidents of violence still remain out of reach of health, education and social assistance teams. 
We believe that accurate reporting is fundamental to understanding the magnitude of the problem of violence in a given territory. Accurate reporting will contribute to an increase in the visibility of the problem and increase aware-

\section{REFERENCES}

1. Souza MKB, Santana JSS. Atenção ao adolescente vítima de violência: participação dos gestores municipais de saúde. Ciênci Saúde Coletiva. 2009;14(2):547-55.

2. World Health Organization. World report on violence and health. Geneva: WHO; 2002.

3. Conselho Nacional dos Direitos da Criança e do Adolescente. Orientações técnicas: Serviços de Acolhimento para Crianças e Adolescentes. Brasília; 2009.

4. Waiselfiz JJ. Mapa da violência 2012: crianças e adolescentes do Brasil. Rio de Janeiro: Centro Brasileiro de Estudos LatinoAmericanos; 2012.

5. Lemos FCS, Guimarães JL, Cardoso Junior HR. A produção da violência doméstica contra crianças e adolescentes. In: Araújo MF, Mattioli OC, organizadoras. Gênero e violência. São Paulo: Arte e Ciência; 2004.

6. Egry EY, Fonseca RMGS, Oliveira MAC. Ciência, saúde coletiva e enfermagem: destacando as categorias gênero e geração na episteme da práxis. RevBrasEnferm. 2013; 66(n.esp):119-33.

7. Protocolo da Rede de Proteção à Criança e ao Adolescente em Situação de Risco para a Violência. Curitiba: Secretaria Municipal da Saúde; 2008.

8. Bardin L. Análise de conteúdo. Lisboa: Edições 70; 2009.

9. Scott J. Gênero: uma categoria útil de análise histórica. Educ Realidade. 1995;20(2):16-28.

10. Sarmento MJ. Gerações e alteridade: interrogações a partir da sociologia da infância. Educ Soc. 2005;26(91):361-78.

11. Instituto Brasileiro de Geografia e Estatística. Censo demográfico 2010 [Internet]. Rio de Janeiro; 2010 [citado 2013 ago. 18]. Disponível em: http://www.ibge.gov.br/home/estatistica/populacao/censo2010/

12. Fonseca RMGS, Egry EY, Nóbrega CR, Apostólico MR, Oliveira RNG. Recurrence of violence against children in the municipality of Curitiba: a look at gender. Acta Paul Enferm. 2012;25(6):895-901.

13. Brasil. Ministério da Saúde; Secretaria de Vigilância em Saúde, Departamento de Vigilância Epidemiológica. Guia de vigilância epidemiológica. 7ạ ed. Brasília; 2009. ness in all social segments of the urgency of the need to act in accordance with the information, with the objective of establishing conditions of life that prevent violence in the household and spaces outside of the family.
14. Apostólico MR, Nóbrega CR, Guedes RN, Fonseca RMGS, Egry EY. Characteristics of violence against children in a Brazilian Capital. Rev Latino AmEnferm. 2012;20(2):266-73.

15. Ristum M. A violência doméstica contra crianças e as implicações da escola. TemasPsicol. 2010;18(1):231-42.

16. Assis SG, Deslandes SF. Abuso físico em diferentes contextos de socialização infanto-juvenil. In: Violência faz mal a saúde. Brasília: Ministério da Saúde; 2006.

17. Guedes RN, Fonseca RMGS, Egry EY. The evaluative limits and possibilities in the Family Health Strategy for genderbased violence. Rev Esc Enferm USP [Internet]. 2013 [cited 2013 June 15];47(2):304-11. Available from: http://www.scielo.br/pdf/reeusp/v47n2/en_05.pdf

18. Justino LCL, Ferreira SRP, Nunes CB, Barbosa MAM, GerkMAS, Freitas SLF. Violência sexual contra adolescentes: notificações nos Conselhos Tutelares, Campo Grande, Mato Grosso do Sul, Brasil.Rev Gaúcha Enferm. 2011;32(4):781-7.

19. Faleiros E. Violência de gênero. In: Tarquette SR, organizadora. Violência contra a mulher adolescente-jovem. Rio de Janeiro: EdUERJ; 2007.

20. Carinhanha JI, Penna LHG. Violência vivenciada pelas adolescentes acolhidas em instituições de abrigamento. Texto Contexto Enferm. 2012;21(1):68-76.

21. Minayo MCS. Violência e saúde. Rio de Janeiro: Fiocruz; 2006.

22. Vasconcelos KL, Ferreira AGN, Oliveira EN, Siqueira DD, Pinheiro PNC. Características da violência sexual sofrida por crianças assistidas por um programa de apoio. Rev RENE. 2010;11(1):38-47.

23. Guedes RN, Silva ATMC, Fonseca RMGS. A violência de gênero e o processo saúde doença das mulheres. Esc Anna Nery RevEnferm. 2009;13(3):631-5.

24. Guedes MEF, Moreira ACG. Gênero, saúde e adolescência: uma reflexão a partir do trabalho com a violência doméstica e sexual. MudançasPsicolSaúde. 2009;17(2):79-91.
Correspondence addressed to: Rosa Maria Godoy Serpa da Fonseca Departamento de Enfermagem em Saúde Coletiva, Escola de Enfermagem da USP Av. Dr. Enéas de Carvalho Aguiar, 419 - Cerqueira César CEP 05403-000 - São Paulo, SP, Brazil. e-mail: rmgsfon@usp.br 